\title{
THERMAL EXPANSION OF BERYLLIUM AND ALUMINUM- BERYLLIUM ALLOYS
}

\author{
By Peter Hidnert and W. T. Sweeney
}

ABSTRACT

The investigation described in this paper was undertaken because no data on the thermal expansion of beryllium or any of its alloys were available. The paper gives results on the linear thermal expansion of beryllium (98.9 per cent) and five aluminum-beryllium alloys containing various percentages of beryllium ( 4 to 33 per cent). Expansion determinations were made over various temperature ranges, between -120 and $+700^{\circ} \mathrm{C}$. on a sample of beryllium, and between room temperature and $500^{\circ} \mathrm{C}$. on the aluminum-beryllium alloys. The expansion curves of beryllium and aluminum-beryllium alloys are shown and discussed.

The average coefficient of expansion of beryllium is $12.3 \times 10^{-6}$ per degree centigrade between 20 and $100^{\circ} \mathrm{C}$. Beryllium expands considerably less than the other elements of subgroup IIB (magnesium, zinc, cadmium, and mercury).

The coefficients of expansion of the aluminum-beryllium alloys decrease with increase in the beryllium content. On a second heating the coefficients are generally larger than the corresponding values obtained in the first heating. The relations between the coefficients of expansion and the chemical composition were compared with the equilibrium diagram obtained by Oesterheld, and were found to be in agreement with the theory.

Figure 10 shows a comparison of the expansion curves of beryllium (98.9 per cent) and the aluminum-beryllium alloys between room temperature and $500^{\circ} \mathrm{C}$. The table in the summary gives a résumé of average coefficients of expansion derived from the data on all samples for various temperature ranges between 20 and $500^{\circ} \mathrm{C}$.

\section{CONTENTS}

II. Materials investigated._.

III. Apparatus_.

IV. Results

1. Beryllium (98.9 per cent)

2. Aluminum-beryllium alloys.

V. Summary _...

\section{INTRODUCTION}

In view of the fact that there was no available information on the thermal expansion of beryllium or any of its alloys, an investigation was recently undertaken to supply data ${ }^{1}$ on this metal and some of its alloys.

1 Some preliminary data on beryllium were presented by the authors to the American Physical Society on Feb. 26, 1927 (Phys. Rev., 29, p. 616; 1927).

$64986^{\circ}-27$ 
This paper gives the results of the investigation on the linear thermal expansion of beryllium and five aluminum-beryllium alloys containing various percentages of beryllium (between 4 and 33 per cent). Expansion determinations were made over various temperature ranges between -120 and $+700^{\circ} \mathrm{C}$. on a sample of beryllium and between room temperature and $500^{\circ} \mathrm{C}$. on the aluminumberyllium alloys. Five tests were made on the specimen of beryllium and two tests on each of the aluminum-beryllium alloys.

The authors wish to express their appreciation for the cooperation by the Beryllium Corporation of America, Cleveland, Ohio. This company furnished the samples of beryllium and aluminum-beryllium alloys, and information about the preparation. Acknowledgment is due to H. W. Bearce, W. Souder, and H. W. Gillett, Bureau of Standards, for valuable suggestions.

\section{MATERIALS INVESTIGATED}

One sample of cast beryllium and five samples of cast aluminumberyllium alloys ( 4 to 33 per cent beryllium) were investigated. Each sample was approximately $300 \mathrm{~mm}$ in length and $10 \mathrm{~mm}$ in diameter.

The following information relating to the casting of beryllium was furnished by the manufacturer:

In melting and casting beryllium our practice has been first to prepare a flux composed of about 10 per cent barium fluoride and 90 per cent barium chloride. This flux after fusion and cooling is ground to a fine powder. The buttons of massive beryllium are placed in a graphite crucible and a small amount of this powdered flux sprinkled on the surface. The crucible is then covered with just the ordinary graphite cover and heated to about 1,350 or $1,400^{\circ} \mathrm{C}$. in a gas furnace. About 5 or 10 minutes before pouring it is advisable to remove the cover and rotate the crucible in order to bring all the particles of metal together in one fluid mass. It is then superheated for about 10 minutes longer and rapidly cast. We might add that in the melting of small amounts, such as 10 to $25 \mathrm{~g}$, some losses are sustained, but in handling larger amounts we have been able to get practically 100 per cent recovery in this manner.

The Beryllium Corporation of America states that virgin aluminum and beryllium containing about 99 per cent beryllium were used in the preparation of the aluminum-beryllium alloys. Iron was the chief impurity in beryllium. The cast alloys were prepared by heating the two metals (aluminum and beryllium) to about 1,100 to $1,200^{\circ} \mathrm{C}$. with a small amount of the fluoride-chloride flux mentioned in the preceding paragraph.

For information about other methods of preparing beryllium and its alloys the reader should refer to recent papers ${ }^{2}$ on this subject.

\footnotetext{
2 Fopkins and Meyer, The electrolytic production of beryllium, Trans. Am. Electrochem. Soc., 45, p. 475: 1924. Engle and Hopkins, The metallurgy and alloys of beryllium, Trans. Am. Electrochem. Soc., 45, p. 483; 1924. Vivian, Beryllium, Trans. Faraday Soc., 22, p. 211; 1926.
} 
Table 1 gives the chemical composition and the densities of the samples investigated. In the alloys the iron impurity increases regularly with the beryllium content.

TABLE 1.-Chemical composition and densities of beryllium and aluminumberyllium alloys ${ }^{1}$

\begin{tabular}{|c|c|c|c|c|c|c|c|c|}
\hline \multirow[b]{2}{*}{ Sample } & \multirow[b]{2}{*}{ Material } & \multicolumn{6}{|c|}{ Chemical analyses ${ }^{2}$} & \multirow{2}{*}{$\begin{array}{l}\text { Density } \\
\text { in } \mathrm{g} / \mathrm{cm}^{3} \\
\text { at } 20^{\circ} \mathrm{C} \text {. }\end{array}$} \\
\hline & & Alumi- & \begin{tabular}{|l|} 
Beryl- \\
lium
\end{tabular} & Silicon & Copper & Iron & $\begin{array}{c}\text { Manga- } \\
\text { nese }\end{array}$ & \\
\hline & & Per cent & Per cent & Per cent & Per cent & Per cent & Per cent & \\
\hline $\begin{array}{l}12234 \\
1224\end{array}$ & Aluminum-beryllium alloy... & (๑) 36.3 & $\begin{array}{l}98.9 \\
32.7\end{array}$ & $\begin{array}{r}0.18 \\
.11\end{array}$ & $\begin{array}{r}0.06 \\
.09 \\
\end{array}$ & $\begin{array}{r}0.90 \\
.84\end{array}$ & $\begin{array}{r}0.20 \\
.06\end{array}$ & $\begin{array}{l}1.835 \\
72.225\end{array}$ \\
\hline 1225 & ..... do & 71.9 & 27.5 & .10 & .08 & .58 & .05 & ${ }^{8} 2.202$ \\
\hline 1226 & .....do do... & 81.0 & 18. 6 & .12 & .11 & .36 & .05 & 2. 242 \\
\hline 1227 & -.do. & 89. 7 & 10. 1 & .12 & .09 & .1 & .01 & 2. 401 \\
\hline 1228 & do. & 95.7 & 4.2 & .10 & .10 & & .01 & 2.4 \\
\hline
\end{tabular}

1 The chemical analyses and the densities were determined after the expansion measurements were made on the samples.

${ }^{2}$ Determined by J. A. Scherrer, of this bureau. Magnesium, calcium, lead, zinc, nickel, and selenium were not detected.

Determined by Miss E. E. Hill, of the volumetric section of this bureau.

- Dr. W. F. Meggers, of this bureau, made a spectrochemical analysis of this sample by means of its spark spectrum. The following additional impurities were found: Chromium, selenium, aluminum, magnesium, calcium, silver (trace), and bismuth (doubtful).

8 The electrical resistivity of this rod of beryllium was determined under the direction of Dr. F. Wenner, of this bureau, and found to be 10.2 microhm-cm at $21.5^{\circ} \mathrm{C}$. Assuming the resistivity temperature coefficient to be 0.004 per degree centigrade, the resistivity at $20^{\circ} \mathrm{C}$. is $10.1 \mathrm{microhm}-\mathrm{cm}$. The value given is probably not in error by as much as 5 per cent.

Not detected.

7 On a second determination the density was found to be $2.224 \mathrm{~g} / \mathrm{cm}^{3}$ at $29^{\circ} \mathrm{C}$.

8 After this density determination the sample was cut into two pieces and additional density determinations were made. The density of these pieces was found to be 2.205 and $2.196 \mathrm{~g} / \mathrm{cm}^{3}$ at $25^{\circ} \mathrm{C}$.

Since there are but few data available on the mechanical properties $^{3}$ of beryllium and beryllium-aluminum alloys, an attempt was made ${ }^{4}$ to determine the tensile properties and hardness of the specimens after the expansion data had been obtained. However, due to the presence of blowholes and inclusions, satisfactory tensile data were not obtained.

It is of interest to note that all the alloys machined readily, although the length of chip decreased rapidly with increasing beryllium content. Kerosene was very beneficial in obtaining a good finish. The beryllium sample could not be machined but was readily ground.

The results of the hardness tests are given in Table 2. The hardness was not very uniform. Each value given is the average of four determinations.

TABLE 2.-Hardness of beryllium and alumium-beryllium alloys

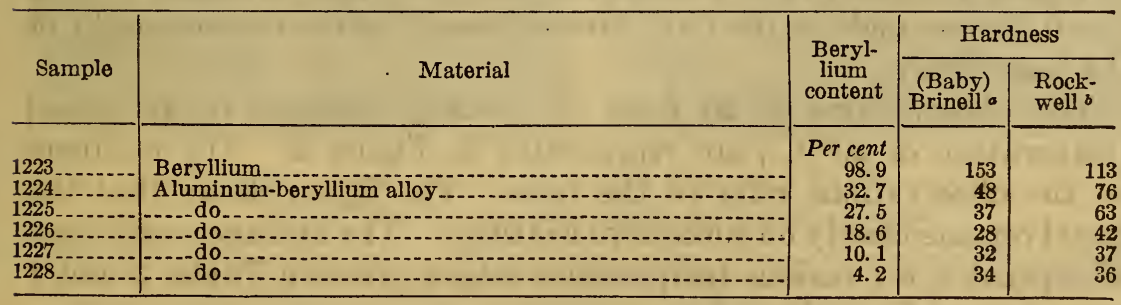

a $6.4 \mathrm{~kg}$ load on $1.6 \mathrm{~mm}$ ball (equivalent to $250 \mathrm{~kg}$ load on $10 \mathrm{~mm}$ ball).

b A one-eighth inch ball, $60 \mathrm{~kg}$ load. These Rockwell hardness numbers are arbitrary and show only relative hardness.

Kroll, Metall. u. Erz, 23, p. 616; 1926; or The Metal Industry, London, 30, p. 645; 1927.

- Under the direction of J. R. Freeman, jr., of the metallurgical division of this bureau. 
Micrographs ${ }^{5}$ showing the structure of the materials investigated are given in Figure 1. No unusual features were noted in the microstructure. A number of cavities were observed in all of the specimens.

\section{APPARATUS}

Figure 1 of Bureau of Standards Scientific Paper No. 524 (vol. 21, p. 1 ; 1926) shows part of the apparatus used in this investigation. With this apparatus the expansion was accurately measured by means of micrometer microscopes, which were sighted on fine wires suspended from or in contact with the ends of the specimen. All expansion tests, except the fourth and fifth tests on sample 1223, were made by the method illustrated in Figure 4 of the paper mentioned. The fourth and fifth tests on sample 1223 were made by the method shown in Figure 3 of the same paper. For a detailed description of the apparatus and the methods used the reader should refer to the original paper.

\section{RESULTS}

The results obtained on beryllium and aluminum-beryllium alloys are given in subsections 1 and 2, respectively. In all cases the coefficients of expansion were derived from the observations on heating.

\section{BERYLLIUM (98.9 PER CENT)}

The linear thermal expansion of a cast rod of beryllium containing 98.9 per cent beryllium was investigated over various temperature ranges between -120 and $+700^{\circ}$ C. Since preliminary work on small pieces of beryllium had shown that this metal oxidized in air at about $800^{\circ} \mathrm{C}$., the maximum temperature of the expansion tests did not exceed this temperature.

Five expansion tests were made on the same rod of beryllium for the following temperature ranges: Test 1 from 20 to $501^{\circ} \mathrm{C}$.; test 2 from 22 to $608^{\circ} \mathrm{C}$.; test 3 from 22 to $705^{\circ} \mathrm{C}$; ; test 4 from -120 to $+19^{\circ} \mathrm{C}$., and test 5 from 16 to $202^{\circ} \mathrm{C}$. Tests 1 to 3 , inclusive, were made in the air furnace marked BS18625 shown at the left of Figure 1 of Bureau of Standards Scientific Paper No. 524. Tests 4 and 5 were made in the bath furnace shown at the extreme right of the same figure.

The observations of all tests on heating, reduced to an initial temperature of $20^{\circ} \mathrm{C}$., are represented in Figure 2. The numbers on the observations refer to the tests. The figure shows that the metal repeats closely on successive heatings. The average coefficients of expansion for various temperature ranges given in Tables 3 and 4 were derived from these data.

\footnotetext{
S Microscopic data by S. Epstein, of the metallurgical division of this bureau.
} 


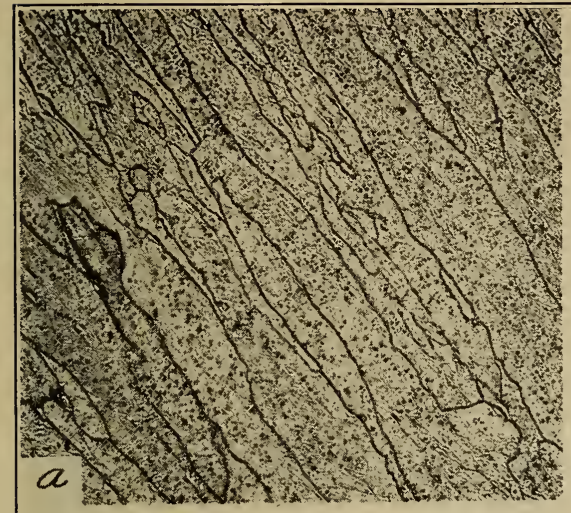

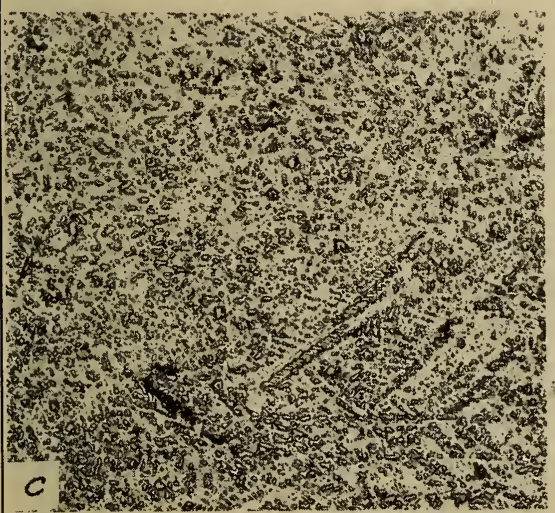
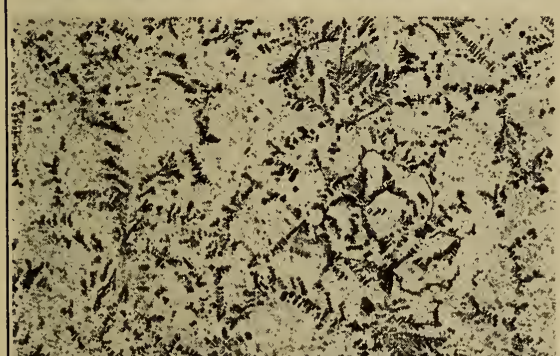

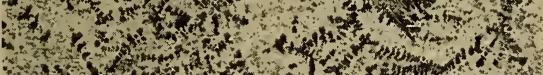

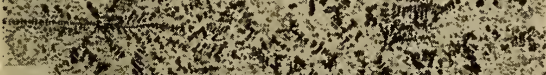

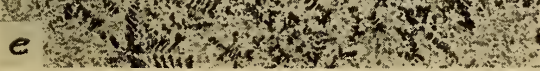
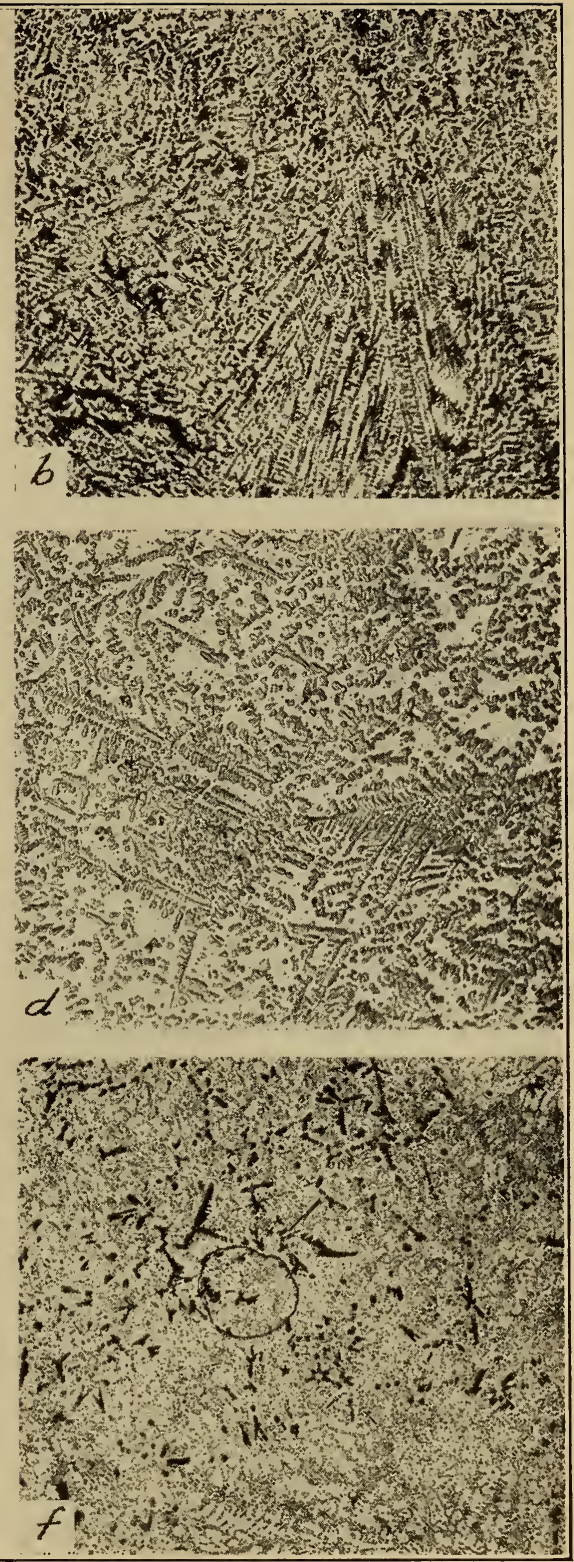

FIG. 1.-Microstructure of cast beryllium and aluminum beryllium alloys. $\quad \times 100$. Etched with 10 per cent sodium hydroxide solution

$a$, Beryllium, 98.9 per cent Be, large crystals of the $\alpha$ phase; $b$, Al-Be, 32.7 per cent $\mathrm{Be} ; c, \mathrm{Al}-\mathrm{Be}, 27.5$ per cent $\mathrm{Be} ; d, \mathrm{Al}-\mathrm{Be}, 18.6$ per cent $\mathrm{Be}$. The matrix is the eutectic and the sharply outlined constituent is the solid solution $\alpha$; $e$, Al-Be, 10.1 per cent $\mathrm{Be} ; f, \mathrm{Al}-\mathrm{Be}, 4.2$ per cent $\mathrm{Be}$

The $\alpha$ constituent appears black in $e$ and $f$, because the specimens for these micrographs were etched longer than those for the preceding three. The eutectic structure of the matrix can be plainly seen.

There is less $\alpha$ constituent in these specimens of low beryllium content 


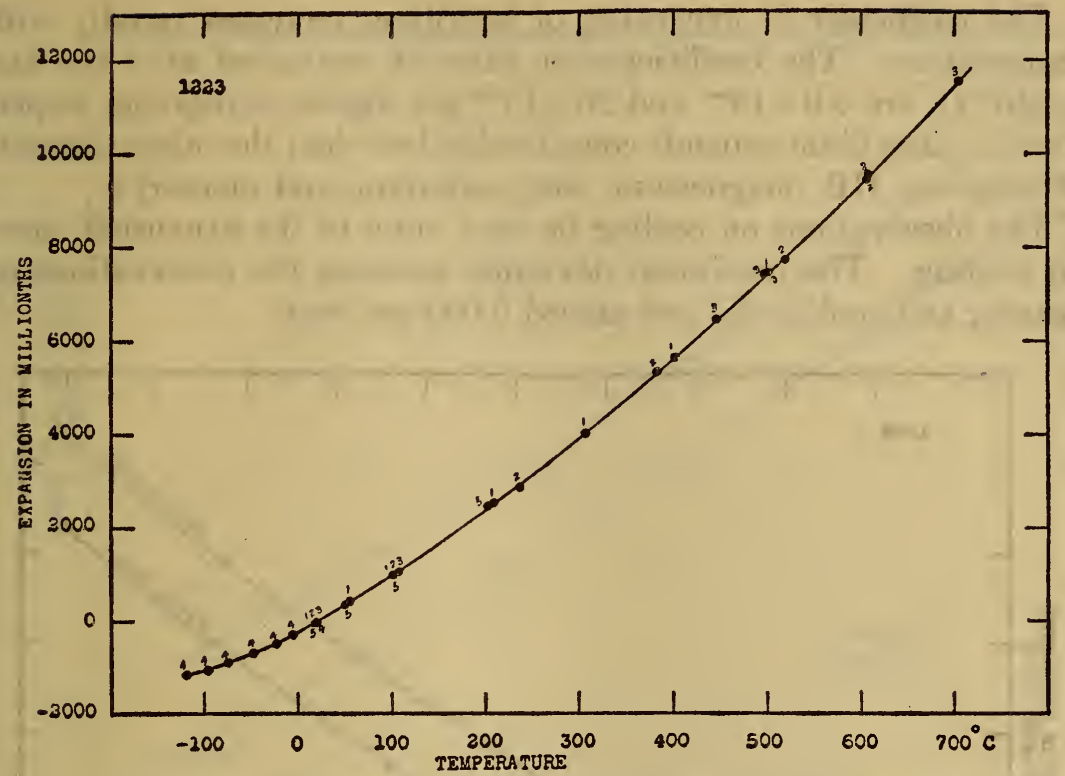

FiG. 2.-Linear expansion of beryllium (98.9 per cent)

TABLE 3.-Average coefficients of expansion of beryllium between -120 and $+20^{\circ} \mathrm{C}$.

\begin{tabular}{|c|c|}
\hline $\begin{array}{l}\text { Temperature range in } \\
\text { degrees centigrade }\end{array}$ & $\begin{array}{l}\text { Average } \\
\text { coefficients } \\
\text { of expan- } \\
\text { sion per } \\
\text { degree } \\
\text { centigrade } \\
\text { (fourth } \\
\text { test) }\end{array}$ \\
\hline $\begin{array}{l}-120 \text { to }-100 \\
-100 \text { to }-50 \\
-50 \text { to } 0 \\
0 \text { to }+20 \\
-120 \text { to } 20\end{array}$ & $\begin{array}{r}\times 10^{-6} \\
5.0 \\
7.0 \\
9.2 \\
11.1 \\
8.1\end{array}$ \\
\hline $\begin{array}{l}-100 \text { to } 20 \\
-50 \text { to } 20 \\
-120 \text { to } 0 \\
-100 \text { to } 0\end{array}$ & $\begin{array}{l}8.6 \\
9.8 \\
7.6 \\
8.1\end{array}$ \\
\hline
\end{tabular}

TABLE 4.-Average coefficients of expansion of beryllium between 20 and $700^{\circ} \mathrm{C}$.

\begin{tabular}{|c|c|c|c|c|c|}
\hline \multirow[b]{2}{*}{ Temperature range in degrees centigrade } & \multicolumn{5}{|c|}{$\begin{array}{c}\text { A verage coefficients of expansion per degree centi- } \\
\text { grade }\end{array}$} \\
\hline & $\begin{array}{l}\text { First } \\
\text { test }\end{array}$ & $\begin{array}{l}\text { Second } \\
\text { test }\end{array}$ & $\begin{array}{l}\text { Third } \\
\text { test }\end{array}$ & $\begin{array}{l}\text { Fifth } \\
\text { test }\end{array}$ & Mean \\
\hline 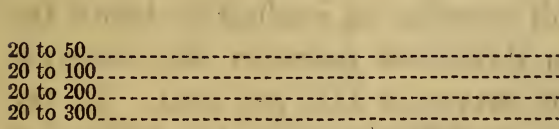 & $\begin{array}{r}\times 10^{-6} \\
11.9 \\
12.2 \\
13.2 \\
13.9\end{array}$ & $\begin{array}{r}\times 10^{-6} \\
12.2 \\
13.0 \\
14.0\end{array}$ & $\frac{\times 10^{-6}}{12.3}$ & $\begin{array}{r}\times 10^{-6} \\
11.8 \\
12.3 \\
13.6\end{array}$ & $\begin{array}{r}\times 10^{-6} \\
11.8 \\
12.3 \\
13.3 \\
14.0\end{array}$ \\
\hline $\begin{array}{l}20 \text { to } 400 \text { to } 500 \\
20 \text { to } 600 . \\
20 \text { to } 700 .\end{array}$ & $\begin{array}{r}14.8 \\
15.5 \\
\end{array}$ & $\begin{array}{l}14.8 \\
15.4 \\
16.0\end{array}$ & $\begin{array}{l}14.8 \\
15.6 \\
16.3 \\
16.8\end{array}$ & $(--\cdot)$ & $\begin{array}{l}14.8 \\
15.5 \\
16.1 \\
16.8\end{array}$ \\
\hline
\end{tabular}


The coefficient of expansion of beryllium increases rapidly with temperature. The coefficients or rates of expansion at -110 and $+650^{\circ}$ C. are $5.0 \times 10^{-6}$ and $20 \times 10^{-6}$ per degree centigrade, respectively. Beryllium expands considerably less than the other elements of subgroup IIB (magnesium, zinc, cadmium, and mercury).

The observations on cooling lie very close to the expansion curve on heating. The maximum deviation between the observations on heating and cooling did not exceed 0.006 per cent.

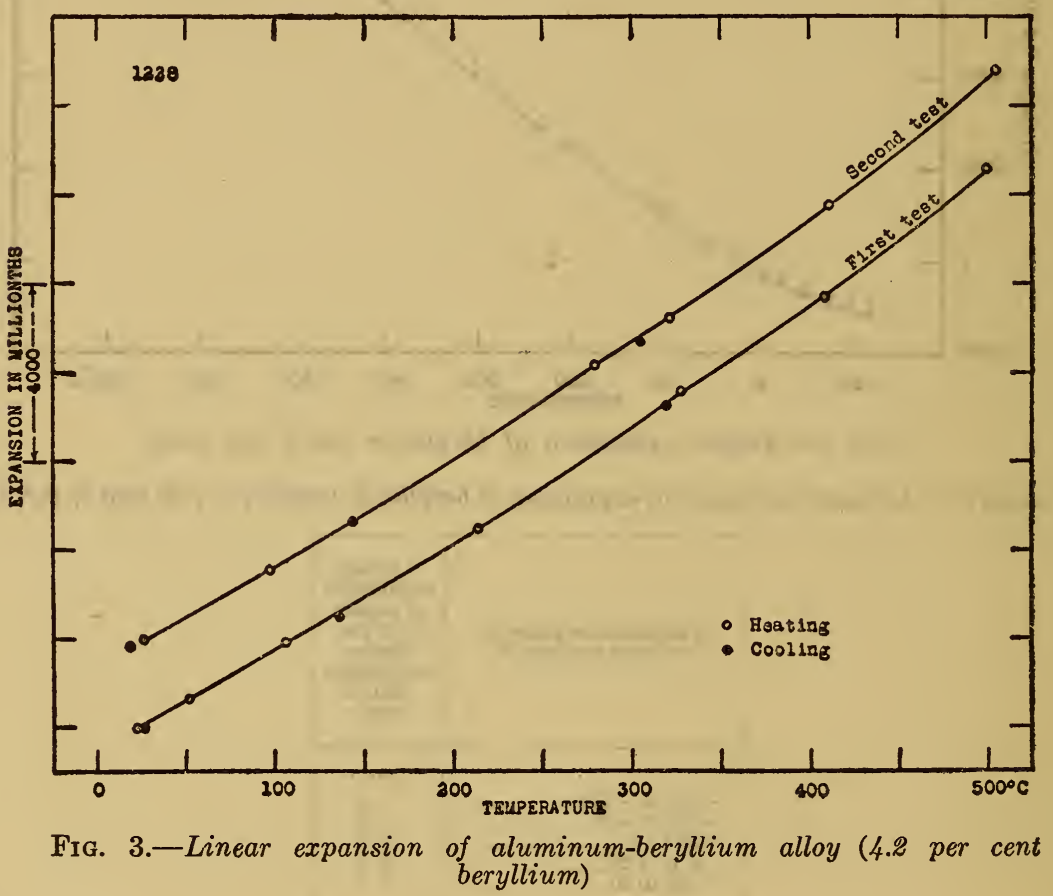

\section{ALUMINUM-BERYLLIUM ALLOYS}

Five cast rods of aluminum-beryllium alloys containing from 4.2 to 32.7 per cent beryllium were investigated over various temperature ranges between room temperature and $500^{\circ} \mathrm{C}$. Two expansion tests were made on each rod in the air furnace mentioned in the preceding subsection.

Figures 3 to 7 , inclusive, show the observations obtained on the aluminum-beryllium alloys. The expansion curves are regular. In the first tests the observations of all samples on cooling lie below the expansion curves. The maximum deviation between the observations on cooling and the expansion curves is 0.03 per cent. In the second tests the observations on cooling lie closer to the expansion curves, due to the heat treatment received during the first tests. 


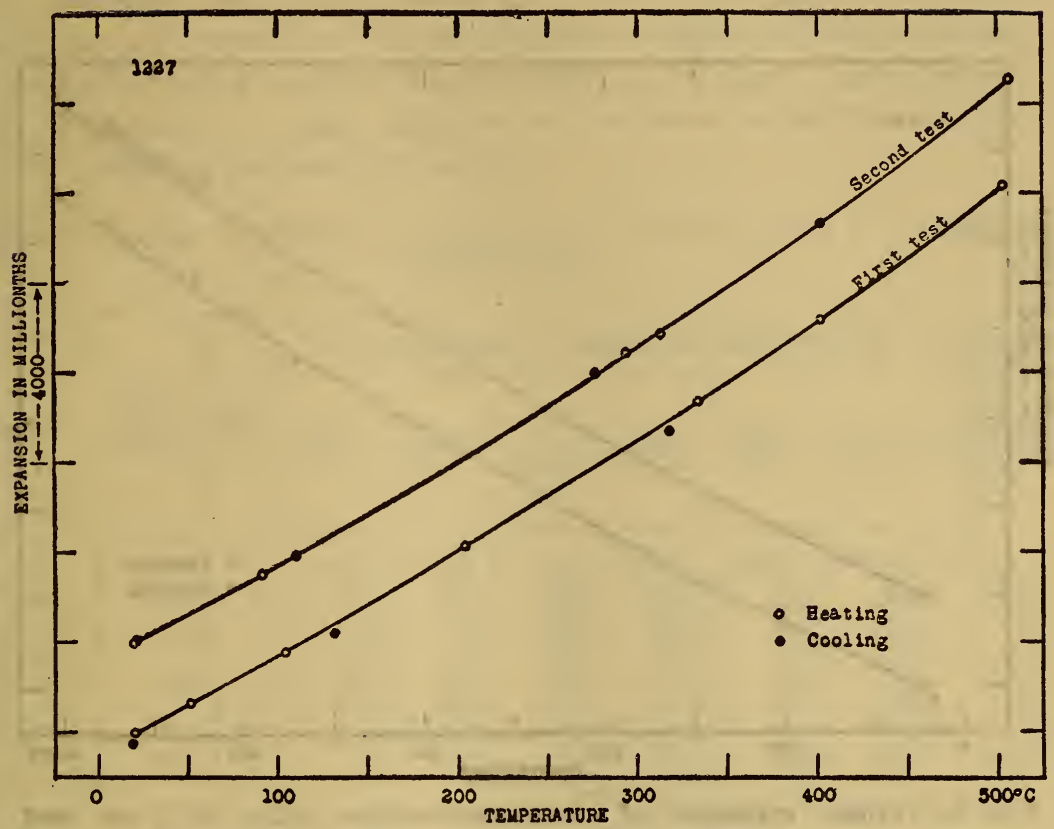

FIG. 4.-Linear expansion of aluminum-beryllium alloy (10.1 per cent beryllium)

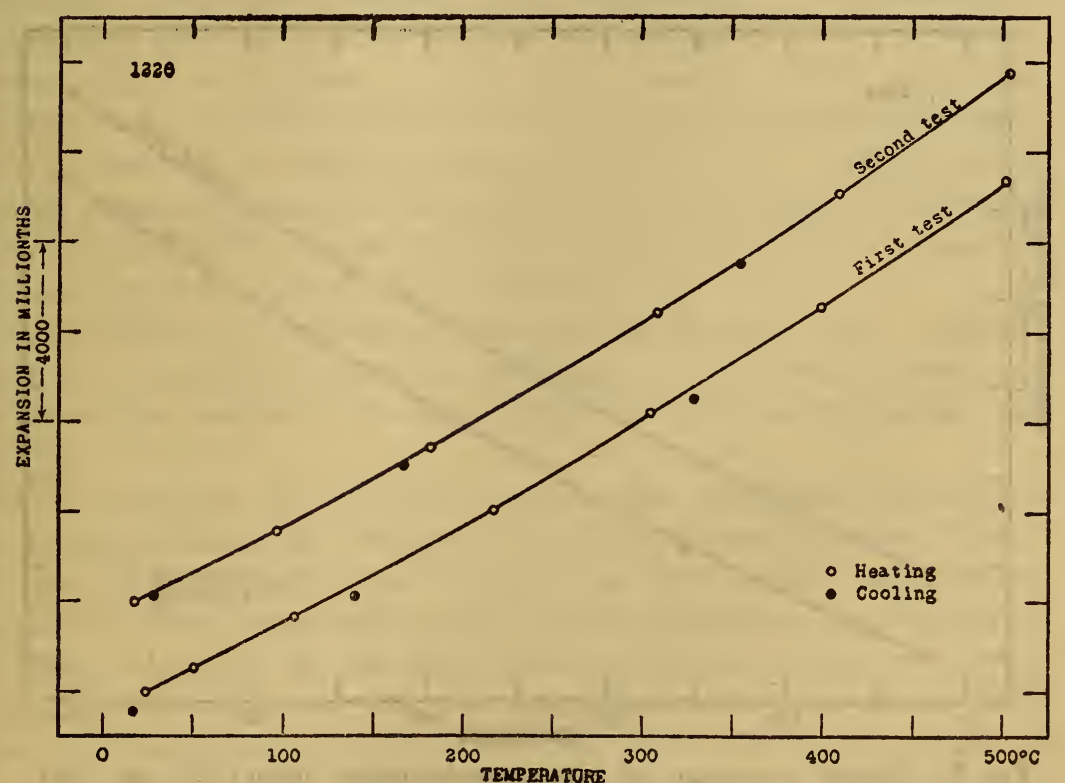

Fig. 5.-Linear expansion of aluminum-beryllium alloy (18.6 per cent beryllium) 


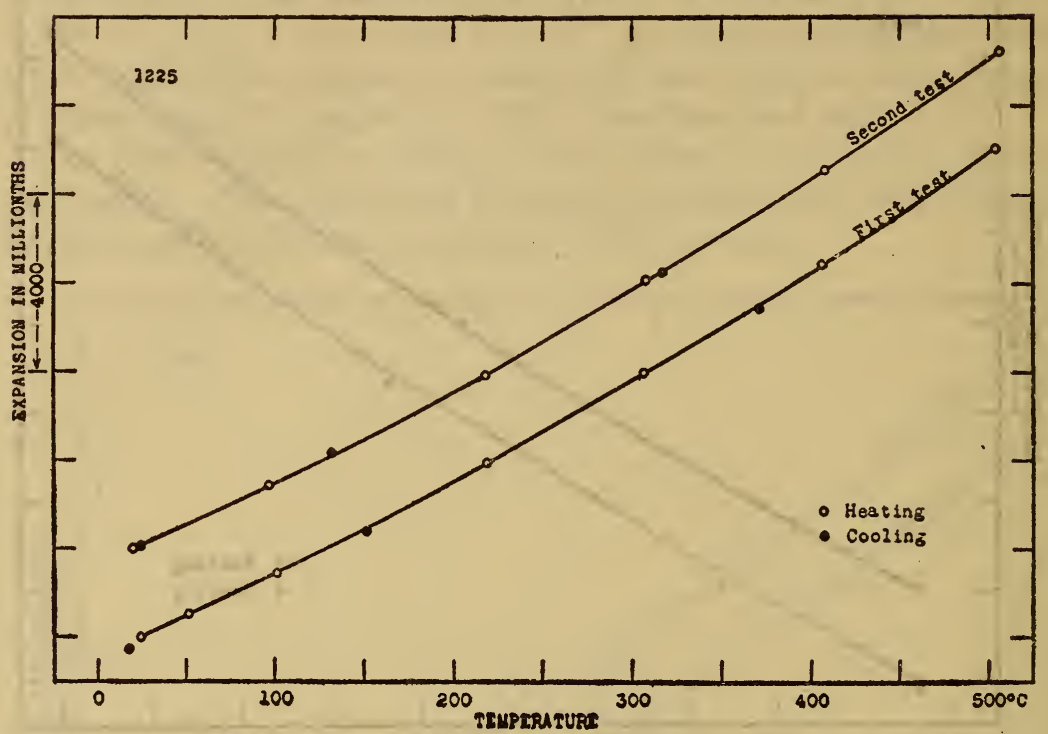

FIG. 6.-Linear expansion of aluminum-beryllium alloy (27.5 per cent

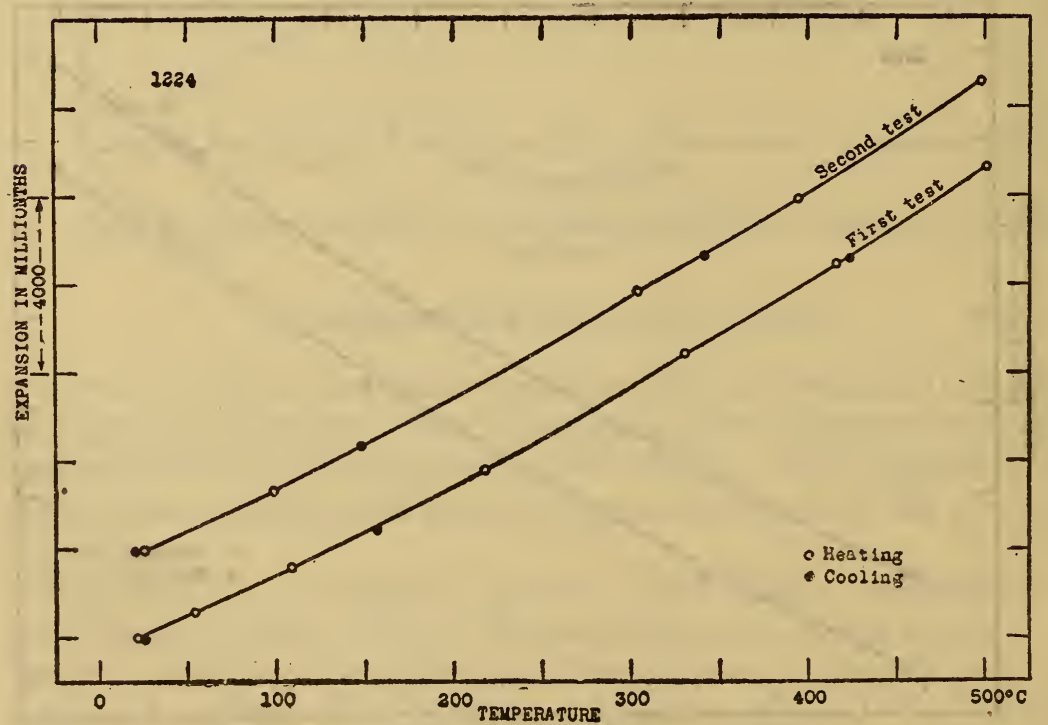

Fia. 7.-Linear expansion of aluminum-beryllium alloy (32.7 per cent 
The average coefficients of expansion given in Table 5 were computed from the expansion curves of the five alloys. This table also indicates the differences in length before and after the expansion tests. The plus $(+)$ sign signifies an increase in length, and the minus $(-)$ sign a decrease in length.

TABLE 5.-Average coefficients of expansion and length changes of aluminumberyllium alloys

\begin{tabular}{|c|c|c|c|c|c|c|c|c|c|}
\hline \multirow{2}{*}{ Sample } & \multirow{2}{*}{$\begin{array}{l}\text { Beryl- } \\
\text { lium } \\
\text { content }\end{array}$} & \multirow{2}{*}{$\begin{array}{l}\text { Test. } \\
\text { No. }\end{array}$} & \multicolumn{6}{|c|}{ Average coefficients of expansion per degree centigrade } & \multirow{2}{*}{$\begin{array}{l}\text { Change } \\
\text { in length } \\
\text { due to } \\
\text { heat } \\
\text { treatment } \\
\text { received } \\
\text { during } \\
\text { test }\end{array}$} \\
\hline & & & $\begin{array}{c}20 \text { to } \\
100^{\circ} \mathrm{C} .\end{array}$ & $\begin{array}{l}20 \text { to } \\
200^{\circ} \mathrm{C} \text {. }\end{array}$ & $\begin{array}{l}20 \text { to } \\
300^{\circ} \mathrm{C} .\end{array}$ & $\begin{array}{l}20 \text { to } \\
400^{\circ} \mathrm{C} \text {. }\end{array}$ & $\begin{array}{r}20 \text { to } \\
500^{\circ} \mathrm{C} .\end{array}$ & $\begin{array}{l}300 \text { to } \\
500^{\circ} \mathrm{C} .\end{array}$ & \\
\hline & Per cent & & $\times 10^{-6} .4$ & $\times 10^{-6}$ & 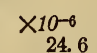 & $\times 10^{-6}$ & $\times 10^{-0}$ & $\times 10^{-6}$ & $\begin{array}{c}\text { Per cent } \\
-0.01\end{array}$ \\
\hline 1227. & 10.1 & $\frac{1}{2}$ & 21.6 & 22.5 & 23. 2 & 24.0 & $\begin{array}{l}20.0 \\
25.2 \\
25.6\end{array}$ & $\begin{array}{l}27.8 \\
27.9\end{array}$ & - - \\
\hline $1226 \ldots$ & 18.6 & 1 & 19.9 & 20.5 & 22.0 & 22.8 & 23.8 & 26.2 & $=$ \\
\hline $1225 \ldots$ & 27.5 & 1 & 19.0 & 20.0 & 21.1 & 21.9 & 22. 9 & 25.4 & -.01 \\
\hline 1224 & 32.7 & $\begin{array}{l}1 \\
2\end{array}$ & $\begin{array}{l}17.9 \\
17.8\end{array}$ & 19 & $\begin{array}{l}20.4 \\
20.8\end{array}$ & $\begin{array}{l}21.3 \\
21.4\end{array}$ & $\begin{array}{l}22.2 \\
22.3\end{array}$ & $\begin{array}{l}24.7 \\
24.4\end{array}$ & $\begin{array}{r}-.01 \\
+.00\end{array}$ \\
\hline
\end{tabular}

An examination of Table 5 shows that the coefficients of expansion of these alloys decrease with increase in the beryllium content. The coefficients of expansion increase with temperature. The coefficients of expansion on the second heating are generally larger than the corresponding coefficients on the first heating. The maximum deviation between the coefficients on the first and second heating is $0.9 \times 10^{-6}$, and the average deviation is $\pm 0.3 \times 10^{-6}$. At the end of the first test on each sample the length was less than the initial length before the test ( 0.01 to 0.03 per cent), but practically no change in length occurred as a result of the second test.

The coefficients of expansion obtained in the first tests represent values for cast alloys, but the coefficients in the second tests are considered to represent results for heat treated or annealed cast material.

Figure 8 shows the relation between the chemical composition (per cent beryllium by weight) of the aluminum-beryllium alloys and the average coefficients of expansion for various temperature ranges. In most cases each plotted value represents an average of the values obtained on the first and second tests. The values for 0 per cent beryllium or 100 per cent aluminum were taken from Bureau of Standards Scientific Paper No. 497. The figure shows, as was noted before, that the coefficients of expansion decrease with increase in the beryllium content. For example, an aluminumberyllium alloy containing 30 per cent beryllium has coefficients of 
expansion approximately 20 per cent less than those of aluminum. This alloy has coefficients which are about the same as those for brass. $^{6}$

For a comparison of the constitution of the aluminum-beryllium alloys and the coefficients of expansion the reader should refer to Figures 8 and 9 . The latter figure shows the aluminum-beryllium equilibrium diagram determined by Oesterheld. ${ }^{7} \mathrm{He}$ found a eutectic at 1.4 per cent beryllium (by weight), at $644^{\circ} \mathrm{C}$. The phase $a$ is a solid solution of aluminum in beryllium. The relation between the chemical composition and the coefficients of expansion

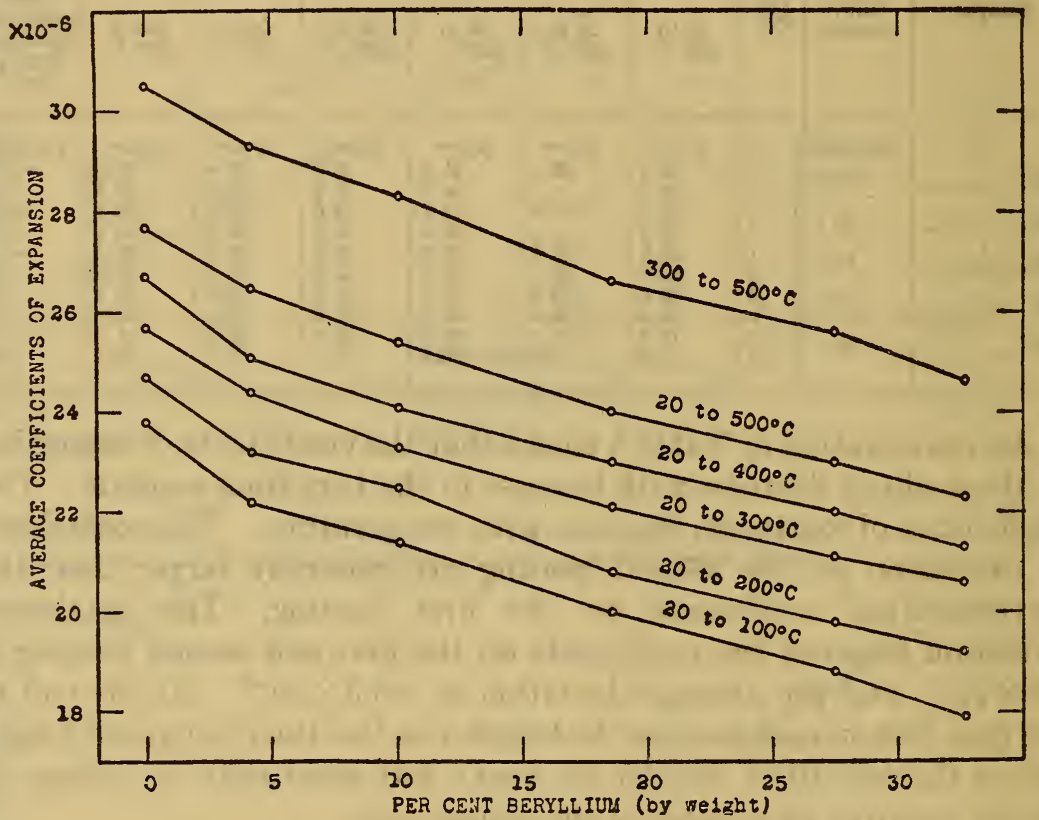

Fig. 8.-Relations between the beryllium content and the coefficients of expansion of aluminum-beryllium alloys

for each temperature range shown in Figure 8 is approximately linear. Linear relations also exist between the coefficients and the atomic percentages of beryllium. This is in agreement with the theory for the type of equilibrium diagram shown in Figure 9.

Figure 10 shows a comparison of the expansion curves of beryllium (98.9 per cent) and the aluminum-beryllium alloys between room temperature and $500^{\circ} \mathrm{C}$. The curve for 0 per cent beryllium or 100 per cent aluminum was taken from the paper ${ }^{8}$ mentioned previously. The expansion curves of the aluminum-beryllium alloys

B B. S. Sci. Paper No. 410.

7 Oesterheld, Zs. anorg. Chem., 97, p. 1; 1916.

${ }^{3}$ B. S. Sci. Paper No. 497. 
shown in this figure represent the data obtained in the second tests on heating. (Figs. 3 to 7 , inclusive.)

Since there is considerable interest in aluminum-beryllium alloys in connection with pistons, it is interesting to compare these expansion curves with the curves for a 12 per cent copper aluminum alloy ${ }^{8}$ and also for cast iron. ${ }^{9}$ The curve for the former is not shown in Figure 10, for its expansion is approximately the same as the expansion of aluminum. However, the expansion curve of a sample of cast iron containing 3.08 per cent carbon and 1.68 per cent silicon is included in the figure.

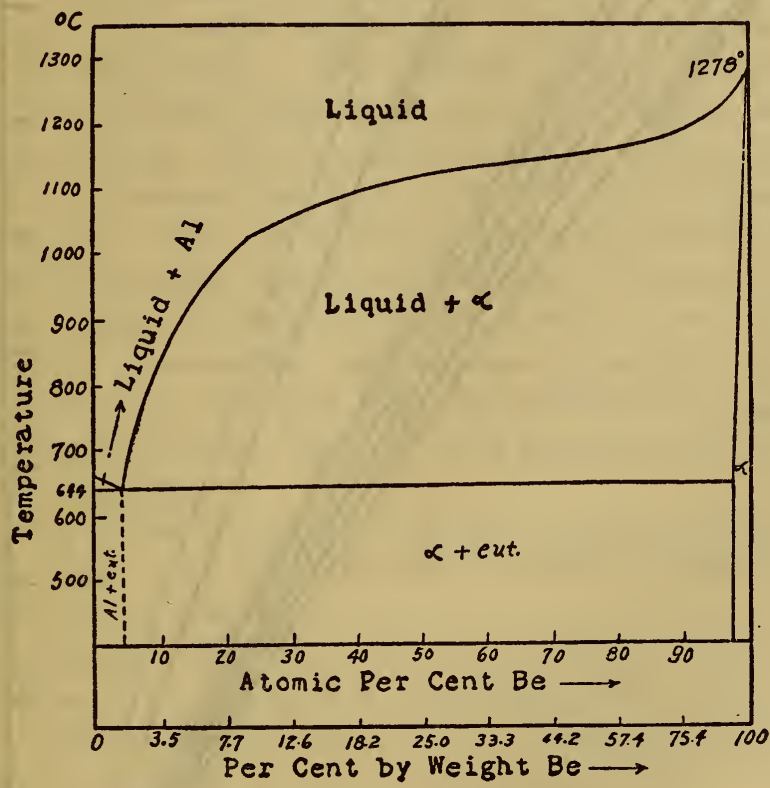

Fıg. 9.-Equilibrium diagram of aluminum-beryllium alloys (after Oesterheld)

\section{SUMMARY}

The investigation described in this paper was undertaken because no data on the thermal expansion of beryllium or any of its alloys were available. The paper gives results on the linear thermal expansion of beryllium (98.9 per cent) and five aluminum-beryllium alloys containing various percentages of beryllium ( 4 to 33 per cent). Expansion determinations were made over various temperature ranges between -120 and $+700^{\circ} \mathrm{C}$. on a sample of beryllium and between room temperature and $500^{\circ} \mathrm{C}$. on the aluminum-beryllium alloys. The expansion curves of beryllium and aluminum-beryllium alloys are shown and discussed.

B. S. Sci. Paper No. 433. 


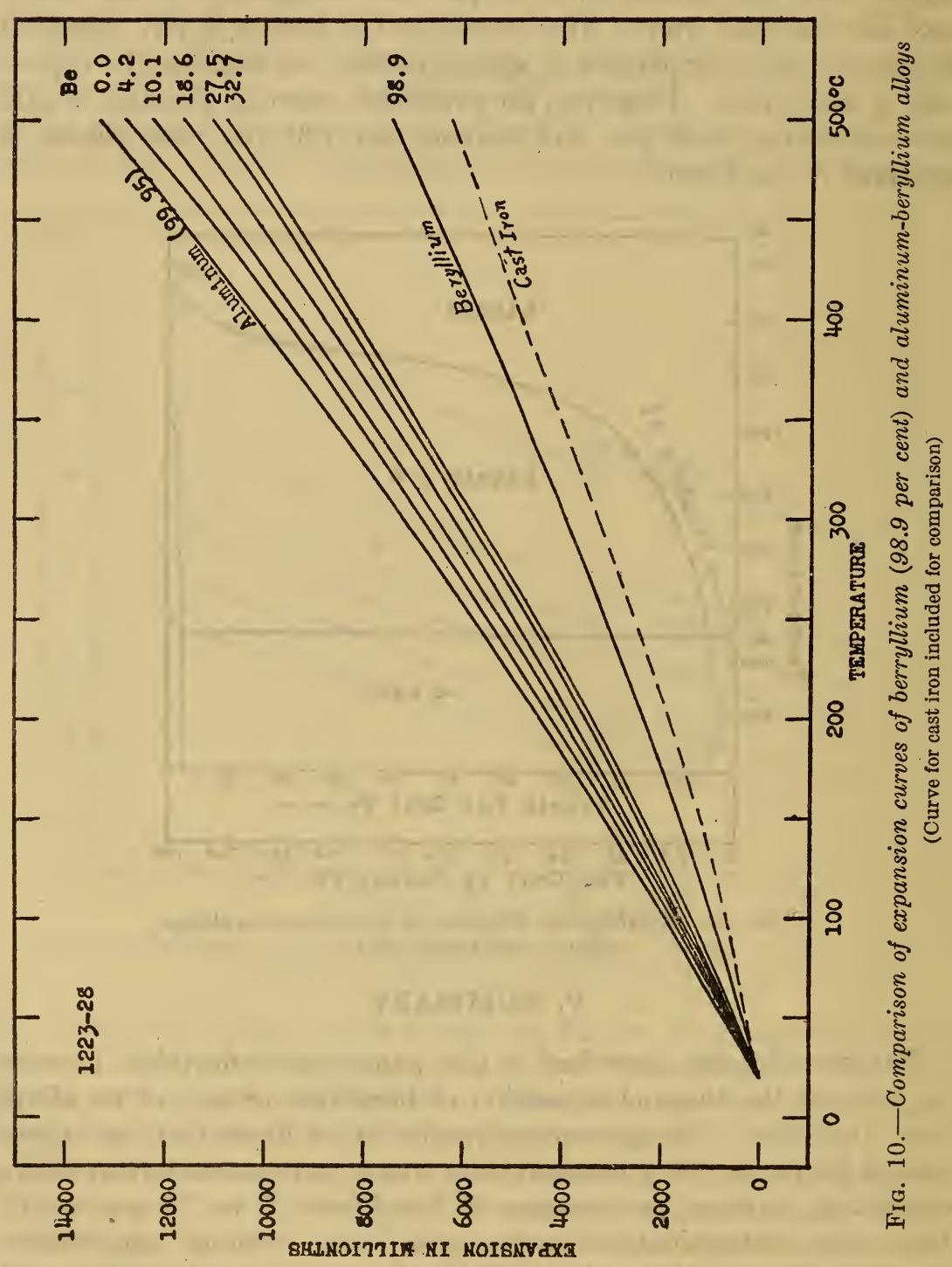


The coefficient of expansion of beryllium increases rapidly with temperature. The coefficients or rates of expansion at -110 and $+650^{\circ} \mathrm{C}$. are $5.0 \times 10^{-6}$ and $20 \times 10^{-6}$ per ${ }^{\circ} \mathrm{C}$., respectively. For the temperature range from 20 to $100^{\circ} \mathrm{C}$. the average coefficient of expansion is $12.3 \times 10^{-6}$ per ${ }^{\circ} \mathrm{C}$. Beryllium expands considerably less than the other elements of subgroup IIB (magnesium, zinc, cadmium, and mercury).

The coefficients of expansion of the aluminum-beryllium alloys decrease with increase in the beryllium content. For example, an aluminum-beryllium alloy containing 30 per cent beryllium has coefficients of expansion approximately 20 per cent less than those of aluminum. The coefficients of the aluminum-beryllium alloys increase with temperature. On a second heating the coefficients of expansion are generally larger than the corresponding values obtained in the first heating. The maximum deviation between the coefficients on the first and second heating is $0.9 \times 10^{-6}$, and the average deviation is $\pm 0.3 \times 10^{-6}$. The coefficients obtained in the first tests represent values for cast alloys, but the coefficients in the second tests are considered to represent results for heat-treated or annealed cast material. The relations between the coefficients of expansion and the chemical composition were compared with the equilibrium diagram obtained by Oesterheld, and were found to be in agreement with the theory for this type of diagram.

Figure 10 shows a comparison of the expansion curves of beryllium (98.9 per cent) and the aluminum-beryllium alloys between room temperature and $500^{\circ} \mathrm{C}$.

The following table gives a résumé of average coefficients of expansion derived from the data on all samples for various temperature ranges between 20 and $500^{\circ} \mathrm{C}$. In most cases, each coefficient represents an average of the values obtained on two or more heatings.

TABLE 6.-Résumé of average coefficients of expansion of beryllium and aluminumberyllium alloys

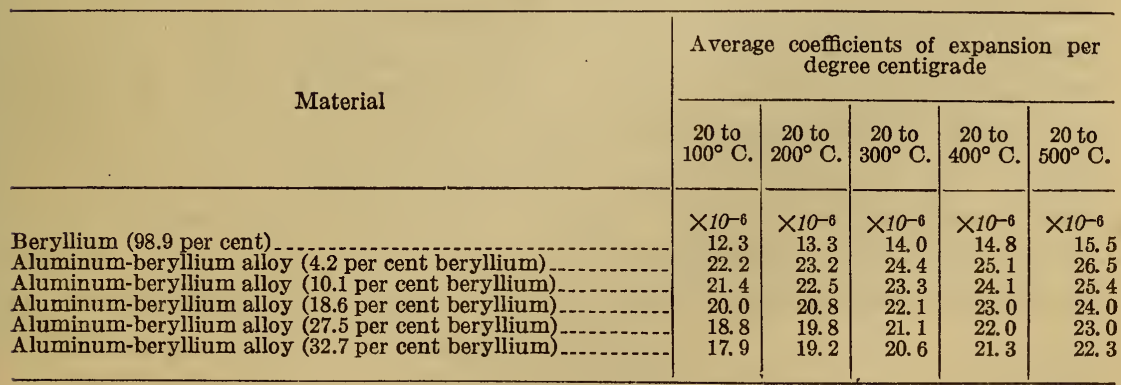

WaShington, July, 1927. 